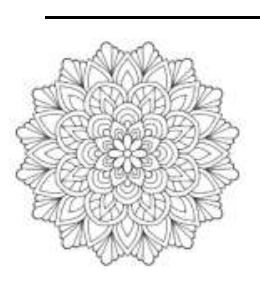

AL HIKMAH: INDONESIAN JOURNAL OF EARLY CHILDHOOD ISLAMIC

EDUCATION

ISSN (P): 2550-2200, ISSN (E): 2550-1100,

VOL. 5 (2), 2021, PP. 152 - 164

http://journal.iaialhikmahtuban.ac.id/index.php/ijecie

\title{
PENGGUNAAN MEDIA VIDEO PEMBELAJARAN DALAM MENINGKATKAN MOTIVASI BELAJAR ANAK USIA DINI DI MASA PANDEMI
}

\author{
Rika Gustiani ${ }^{1}$, Ine Nirmala. ${ }^{2}$, Feronica Eka Putri ${ }^{3}$ \\ ${ }^{123}$ Pendidikan Islam Anak Usia Dini, Fakultas Agama Islam, Universitas Singaperbangsa Karawang \\ rikagustiani773@gmail.com \\ Abstrak
}

\begin{abstract}
Artikel penelitian ini bertujuan untuk mendeskripsikan proses dan hasil pembelajaran menggunakan media video pembelajaran yang dibuat guru dalam meningkatkan motivasi belajar anak dimasa pandemi. Berdasarkan hasil observasi awal menyimpulkan bahwa motivasi belajar anak di KB Baitul falihin masih rendah, yaitu sebesar 40,5\%. Penelitian ini dilakukan di KB Baitul Falihin, Karawang pada bulan Juni 2021. Subjek penelitian ini adalah anak usia 5-6 tahun yang berjumlah 10 anak. Metode penelitian yang digunakan adalah penelitian tindakan kelas. Teknik pengumpulan data melalui observasi, wawancara dan dokumentasi. Teknik analisis data yang digunakan dalam penelitian ini adalah analisis data kualitatif dan kuantitatif. Analisis data kuantitatif digunakan untuk menentukan presentase kenaikan motivasi belajar anak setelah dilakukan Tindakan. Analisis kualitatif digunakan untuk mendeskripsikan hasil penelitian. Hasil penelitian menunjukkan peningkatan motivasi belajar anak setelah pembelajaran menggunakan media video pembelajaran. Berdasarkan hasil penelitian yang dilaksanakan pada siklus I dan Siklus II, hasil dari Siklus I menunjukan adanya peningkatan sebesar $50,4 \%$, dan pada siklus ke II menunjukkan peningkatan sebesar $79,2 \%$. Hasil tersebut dapat dijadikan acuan untuk guru dapat menggunakan media video pembelajaran sebagai media untuk meningkatkan motivasi belajar anak
\end{abstract}

Kata Kunci: motivasi belajar anak, video pembelajaran, pandemi covid 19
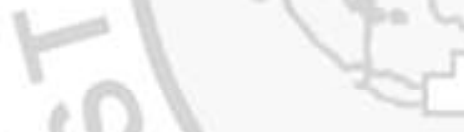

\section{Abstract}

This research article aims to describe the process and result of learning using instructional video media made by teachers in increasing children's leaning motivation during the pandemic. This research was conducted at Baitul Falihin KB, Karawang in June 2021. The subjects of this study were children aged 5-6 years, totaling 10 children's. The research method used in classroom action research. Data collection techniques are through observation, interviews and documentation. Data analysis techniques used in this study are qualitative and quantitative data analysis. Quantitative data analysis is used to determine the percentage increase in children's learning motivation after the action. Qualitative analysis is used to describe the research result. The results showed an increase in children's learning motivation after learning using learning video media. Based on the results of research conducted in cycle I and cycle II, the results of cycle I showed an increase of $50.4 \%$, and in the second cycle showed an increase of $79.2 \%$. These results can be used as a reference for teachers to use learning video media as a medium to increase children's motivation.

Keywords: Children's learning motivation, Learning videos, Covid 19 pandemic 


\section{PENDAHULUAN}

Pendidikan anak usia dini merupakan jenjang Pendidikan sebelum Pendidikaan Dasar (SD). Pendidikan anak usia dini bertujuan untuk memberikan stimulus pada anak berupa pemberian stimulus berupa sensori motoric, psikomotorik, kognitif agar anak dapat memiliki keterampilan untuk ke jenjang Pendidikan dasar. Secara umum proses Pendidikan anak usia dini lebih diutamakan pada metode bermain sambil belajar. Metode bermain sambil belajar diterapkan sesuai dengan kondisi anak - anak yang cenderung lebih suka bermain. Pandemik Covid -19 merupakan virus yang mudah menyebar melalui droplet ,banyak cara yang dilakukan pemerintah untuk mencegah penyebarannya, salah satunya adalah dengan mengalihkan semua kegiatan pembelajaran di sekolah dipindahkan ke rumah .Dalam hal ini Kemendikbud menginstruksikan menyelenggarakan pembelajaran jarak jauh melalui penerapan School from home (SFH). Selama pembelajaran dari rumah guru harus tetap mengawasi, menilai dan mengevaluasi setiap kegiatan yang diberikan kepada anak didik melalui peran serta orangtua dirumah

Berdasarkan hasil observasi awal, kondisi umum pelaksanaan kegiatan pembelajaran sebelum pandemi,anak datang kesekolah dari hari Senin sampai dengan hari Jum'at. Setelah diberlakukannya pembelajaran dari rumah, pembelajaran dirubah menjadi pemberian tugas yang diberikan melalui orangtua murid. Tugas diberikan seminggu sekali setiap hari Senin, orangtua murid mengambil bahan kegiatan tugas yang telah disiapkan oleh walikelas ke sekolah, dan untuk mendapatkan penjelasan langsung dari guru kelas berkaitan tema yang akan dipelajari anak selama satu pekan kedepan dan memberikan arahan tugas yang diberikan untuk mengurangi kesalahan dalam pengerjaan tugas. Tugas berupa pengisian buku LKS, praktek kecakapan, hidup,menunjukkan hasil karya, membuat video kegiatan yang menampilkan anak ketika melakukan kegiatan, voice note untuk hapalan-hapan dan bentuk penugasan lainya. Setelah berjalan 3 bulan dengan metode penugasan tanpa penjelasan langsung dari guru ke peserta didik mengakibatkan peserta didik di KB Baitul Falihin pada saat pengumpulan tugas banyak yang tidak mengirmkan tugas yang diberikan guru, baik tugas hapalan, kegiatan unjuk kerja dan unjuk karya. Selain itu laporan dari orangtua murid mengeluhkan kondisi anakanaknya yang malas malasan pada saat diminta untuk mengerjakan tugas, anak kurng focus,anak kurang semangat,anak kurang memahami materi,tidak ada tanggung jawab dalam mengerjakan tugas, anak malas bangunpagi, anak lebih banyak mengandalkan orangtua, anak terlihat tidak antusias dalam belajar, anak merasa bosan dan merasa bahwa mereka tidak sedang bersekolah karena tidak bertatap muka dengan guru dan teman-temannya. 
Rika Gustiani dkk (Penggunaan Vidio Pembelajaran Dalam Meningkatkan Motivasi Belajar)

Berdasarkan hasil pengamatan awal yang peneliti lakukan, menyimpulkan bahwa motivasi belajar anak di KB Baitul Falihin selama masa pandemik masih rendah,yaitu sebesar 40,5\%. Faktor-faktor yang menyebabkan rendahnya motivasi belajar anak adalah belum munculnya hasrat dan keinginan berhasil, belum munculnya dorongan dan kebutuhan dalam belajar, belum munculnya harapan dan cita-cita masa depan, belum munculnya penghargaan dalam belajar, belum adanya kegiatan yang menarik dalam belajar yang sesuai dengan kebutuhan anak yang mengakibatkan kegiatan pembelajaran menjadi kurang menarik

Dari pemaparan diatas maka guru perlu mengupayakan menimbulkan motivasi belajar anak, sehingga permasalahan yang timbul karena kurangnya motivasi dapat diatasi dengan cara yang benar. Maka solusi yang digunakan adalah dengan menggunakan media video pembelajaran yang dibuat oleh guru, dengan harapan akan memberikan motivasi belajar pada peserta didik selama dirumah yang dampaknya peserta didik akan merasa seperti hadir disekolah, rajin dan tekun mengerjakan aktivitas belajar, mulai muncul rasa ingin tahu, mandiri dalam belajar, merasa senang mengikuti pembelajaran karena sesuai dengan tema dan kebutuhan peserta didik.

Penelitian ini bertujuan untuk mengetahui penggunaan media video pembelajaran dalam meningkatkan motivasi belajar anak usia dini di masa pandemi. Penggunaan media video pembelajaran pada masa pandemi dapat dijadikan alternatif bagi guru dalam pembelajaran daring. Media pembelajaran merupakan suatu alat yang berfungsi sebagai daya dukung keefektifan kegiatan belajar, terutama untuk anak usia dini yang diharuskan belajar dari rumah selama masa pandemi Covid-19 untuk mengurangi penyebaran covid-19 (Batubara, 2020:75). Menurut Cheppy (2007:8) mengemukakan bahwa media video pembelajaran adalah media yang menampilkan rekaman kegiatan pembelajaran yang berisi pesan-pesan pembelajaran berupa prinsip dan prosedur untuk membantu pemahaman terhadap suatu materi pembelajaran. Terdapat dua jenis video sebagai media pembelajaran, pertama video yang sengaja dibuat atau didesain untuk pembelajaran. Jenis video ini dapat menggantikan guru dalam mengajar. Media video ini bersifat interaktif terhadap anak. Kedua video yang di desain secara tidak langsung untuk pembelajaran tetapi dapat dimanfaatkan untuk menjelaskan sesuatu hal yang berkaitan dengan pembelajaran, misalnya video tutorial membuat kreasi, misalnya kreasi menbuat plastisin untuk anak. Dengan menggunakan media pembelajaran diharapkan dapat membuat kegiatan belajar mengajar menjadi menarik buat anak sehingga akan meningkatkan kualitas hasil belajar anak. 
Rika Gustiani dkk (Penggunaan Vidio Pembelajaran Dalam Meningkatkan Motivasi Belajar)

Penggunaan media video pembelajaran dapat memberikan stimulus dan motivasi kepada anak. Motivasi berawal dari kata motif. Hakekat motivasi belajar adalah perubahan tingkah laku terhadap proses belajar yang timbul dari diri sendiri maupun dorongan faktor luar. Motivasi muncul karena adanya kebutuhan, keinginan dan tujuan tertentu untuk mencapai hasil yang diharapkan. Menurut B Uno (2016:23) Indikator motivasi belajar terdiri dari: (1) adanya hasrat dan keinginan berhasil, (2) adanya dorongan dan kebutuhan dalam belajar, (3) adanya harapan dan cita-cita masa depan, (4) adanya penghargaan dalam belajar, (5) adanya kegiatan yang menarik dalam belajar, (6) adanya lingkungan belajar yang kondusif.

Motivasi merupakan kekuatan tingkah laku individu yang disebabkan asanya keiginan yang muncul dalam dirinya untuk mencapai tujuan tertentu. Tinggi rendahnya kesiapan anak untuk belajar sangat ditentukan oleh tinggi rendahnya motivasi anak tersebut. Anak yang mempunyai motivasi tinggi untuk belajar adalah anak yang selalu bersemangat menyelesaikan kegiatan, anak menunjukkan keinginan mengerjakan secara maksimal. Pencapaian prestasi yang tinggi menunjukkan timbulnya motivasi. Dengan adanya motivasi yang tinggi dalam hal belajar akan menunjukkan hasil belajar yang baik pula, sehingga peningkatan keberhasilan belajar anak dalam pembelajaran sangat dipengaruhi oleh motivasi yang ada pada anak itu sendiri.

\section{METODE}

Penelitian ini menggunakan pendekatan Penelitian Tindakan Kelas (PTK) yang pelaksaananya 2 siklus dengan melalui empat tahapan yaitu: 1) Perencanaan (Planing), 2) Tindakan (Acting), 3) Pengamatan (Observasi), 4) Refleksi (Reflecting). Berikut alur penelitian menurut Arikunto (2009: 16)

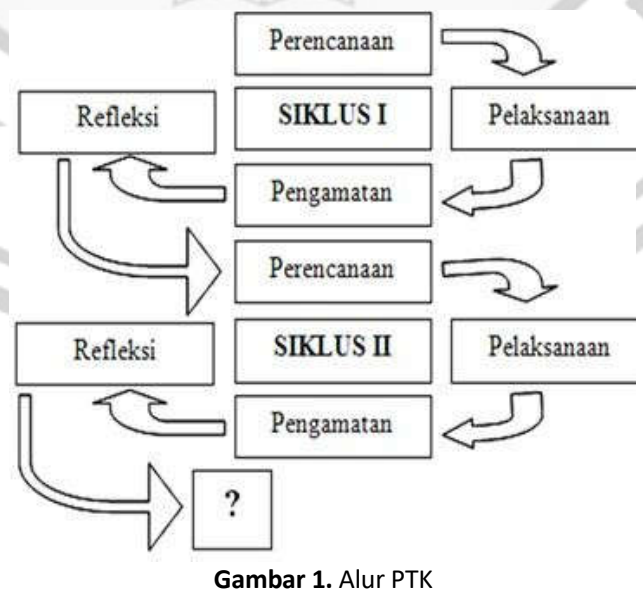

Refleksi dilaksanakan setelah siklus I berakhir. Segala aktivitas kegiatan mulai dari perencanaan hingga berakhirnyaa siklus I diolah datanya, kekurangan yang mungkin masih ada 
Rika Gustiani dkk (Penggunaan Vidio Pembelajaran Dalam Meningkatkan Motivasi Belajar) pada silkus I ditulis dan dilaporkan sebagai bahan perbaikan pada siklus II. Kekurangan yang disarankan pada siklus I dijadikan acuan dalam pelaksanaan siklus II. Siklus II ini untuk menyempurnakan kakurangan -kekurangan yang ditemukan pada siklus I, dengan tujuan setelah adanya perbaikan dan penyempurnaan pada siklus II hasilnya akan lebih baik dibanding pada silkus I. tetapi jika setelah dua silkus tersebut dilaksanakan indikator keberhasilan motivasi belajar belum tercapai maka akan dilaksanakan siklusberikutnya dengan tahapan yang sama dengan siklusI dan siklus II hingga tercapainya indikator keberhasilan sesuai dengan yang telah disepakti.

Penelitian dilaksanakan di KB Baitul Falihin Karawang pada bulan Juni TA 2020-2021. Subjek penelitiannya adalah Kelas (Ar Rahiim) dengan usia 5-6 tahun berjumlah 10 anak, Teknik pengumpulan data melalui observasi, dokumentasi dan wawancara. Pengisian lembar pengamatan dengan memberi tanda score 1,2,3,4.

Tabel 1. Kisi-kisi instrument Motivasi belajar anak

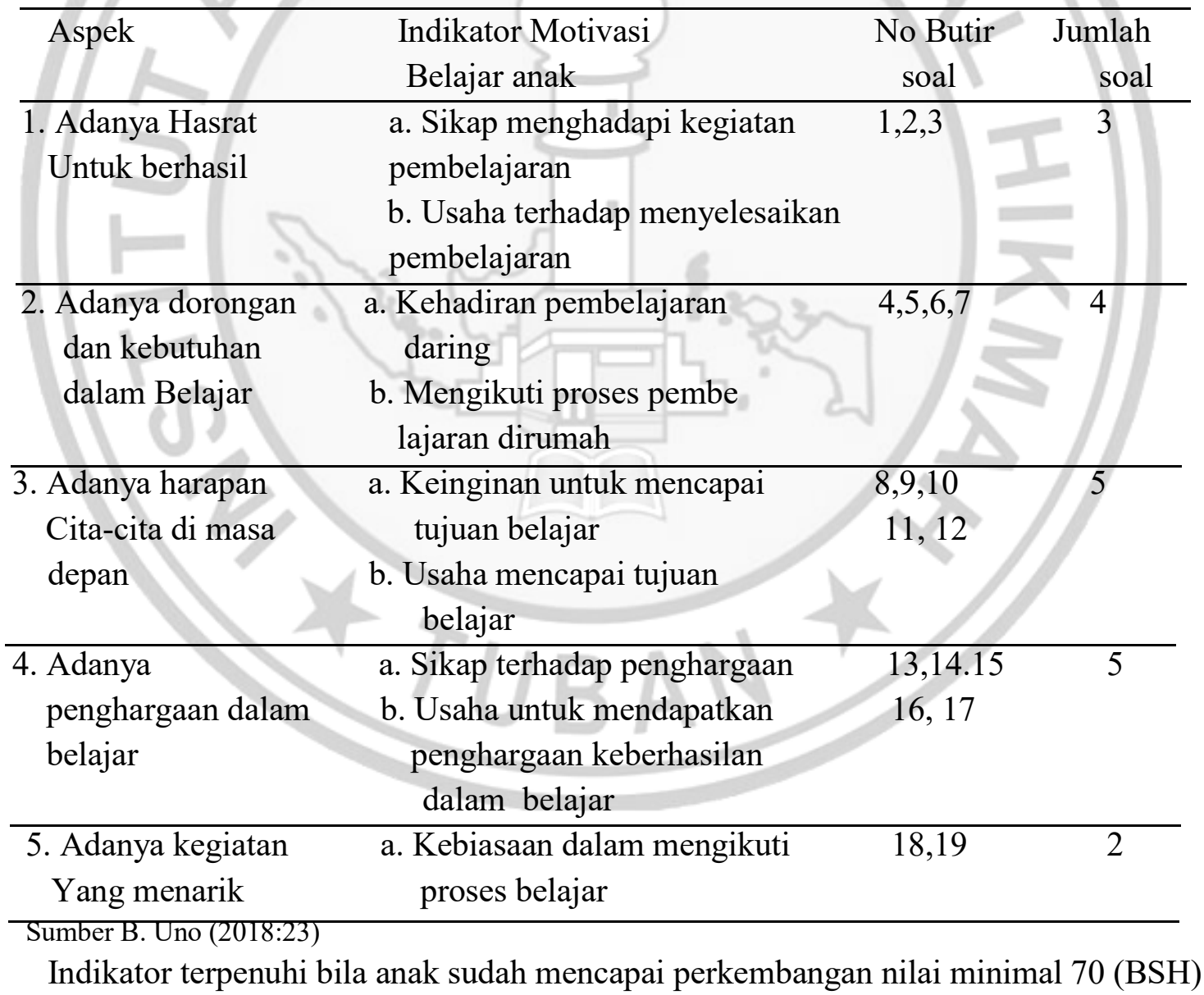

\section{HASIL DAN PEMBAHASAN}




\section{Pra Siklus}

Sebelum peneliti melaksanakan Siklus I, peneliti melakukan pra penelitian yang bertujuan mencari dan mengumpulkan data awal motivasi belajar anak yang akan diteliti melalui observasi dan melalui wawancara dengan guru kelas pada tanggal 10 Juni 2021. Hasil observasi menyimpulkan bahwa motivasi anak yang terdiri dari 5 aspek motivasi belajar di KB Baitul Falihin masih rendah. Pelaksanaan pra siklus menunjukkan bahwa dari 10 anak terdapat $40,5 \%$ anak masih belum menunjukkan kemampuan motivasi belajar dengan indikator sikap anak dalam menghadapi kegiatan pembelajaran belum muncul, usaha anak terhadap menyelesaikan kegiatan belum muncul, kehadiran anak dalam pembelajaran daring belum muncul,mengikuti proses pembelajaran dirumah, belum muncul keinginan untuk mencapai tujuan belajar belum muncul, kemampuan anak untuk mengetahui rasa keingin tahuan yang tinggi belum muncul, sikap anak dalm mengerjakan kegiatan secara mandiri dalam belajar belum muncul, sikap anak menghadapi pertanyaan yang diberikan orantua ketika pembelajaran belum muncul Berdasarkan hasil pra penelitian tersebut diperlukan perbaikan dalam kegiatan pembelajaran, maka untuk meningkatkan motivasi belajar anak solusi yang digunakan adalah dengan menggunakan media video pembelajaran yang dibuat oleh guru.

Penilaian pra siklus dilihat dari 5 aspek motivasi belajar, persentase awalnya adalah AA $39,5 \%$, DI $38,2 \%$, DN 39,5\%, EA $38,2 \%$, MR 34,2\%, MI 56,6\%, NA 39,5\%, MZ 42,1\%, PA 26,3\%, MA 51,3\%, sedangkan rata-rata persentasenya sebesar 40,5\%. Hasil menunjukkan terdapat 3 anak yang memiliki nilai diatas rata-rata 40,5\%.

Berikut adalah grafik motivasi belajar anak pra siklus

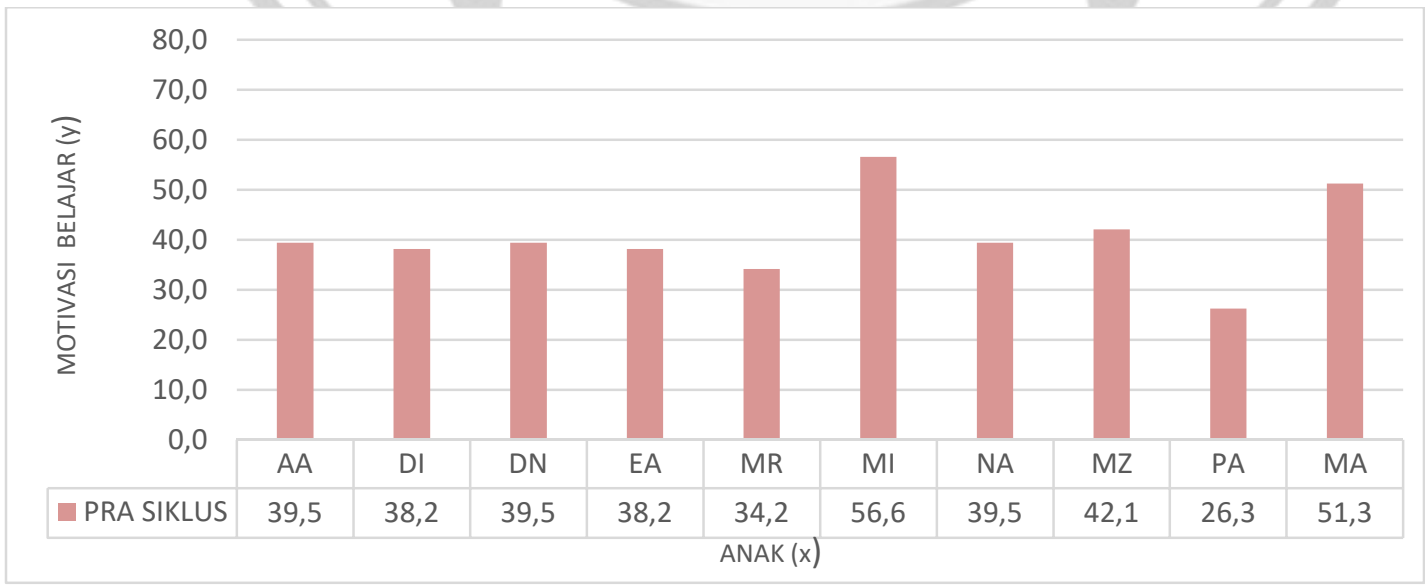

Grafik 1. Motivasi Belajar anak pra siklus 
Grafik 1 menunjukkan persentase motivasi belajar anak usia 5-6 tahun di KB Baitul Falihin pada pra siklus yang berjumlah 3 anak yang tertinggi dari seluruh aspek penilaian motivasi belajar diperoleh oleh MI yaitu sebesar 56,6\%, MA 51,3\%, MZ 42,1\%. Dengan demikian anak yang memiliki persentase skor dibawah rata-rata 7 anak. Skor awal tersebut menjadi acuan dasar penelitian ini untuk meningkatkan motivasi belajar anak di KB Baitul Falihin. Setelah itu dilakukan pendataan masalah yang berhubungan dengan motivasi belajar anak Kemudian direncanakan refleksi bersama guru untuk memperbaiki hasil skor anak yang belum maksimal dan mengoptimalkkan hasil belajar anak disiklus berikutnyan, dengan menggunakan media video pembelajaran yang dibuat guru kepada anak usia 5-6 tahun di KB Baitul falihin.

\section{Siklus I}

Tindakan dimulai pada tanggal 10 Juni 2021, terlebih dahulu peneliti dan guru menyiapkan beberapa persiapan yaitu: a) Menyusun rencana kegiatan, tema yang dipakai adalah Tanah Airku sub tema negaraku, b) mempersiapkan RPPH, c) membuat video pembelajaran, d) menyediakan format penilaian, f) menyediakan lembar refleksi.

Tindakan dilaksanakan dalam 8 kali pertemuan berdasarkan tema pembelajaran yang telah ditentukan. Berikut ragam kegiatan pada Siklus I: 1. Meniru tulisan nama Pulau di Indonesia, 2. Menyebutkan lambang Pancasila, 3. Memberi tanda centang untuk bendera Indonesia, 4. Bernyayi lagu Garuda Pancasila, 5. Membuat kolase Bendera Merah Putih, 6. Hapalan Hadist Berkata Baik, 7. Malakukan praktek 7 langkah mencuci tangan, 8 Pembiasaan sholat dhuha. Tindakan diakhiri oleh guru dan peneliti pada setiap pertemuannya. Refleksi dilakukan setelah mendapat kiriman kegiatan yang dikirim oleh orangtua melalui Whatsapp grup.

Refleksi yang dihasilkan guru selama siklus I bahwa media video pembelajaran mampu menarik minat anak untuk melakukan kegiatan pembelajaran,tetapi perlu perbaikan pada siklus selanjutnya. Peneliti dan guru membuat video pembelajaran disekolah dengan materi yang telah ditentukan secara natural tanpa editan kemudian dikirim ke Whatsapp grup kelas tetapi hal ini cenderung membuat anak cepat bosan dengan video yang ditampilkan.Hasil refleksi tersebut menjadi pertimbangan untuk siklus selanjutnya.

Hasil observasi peningkatan motivasi belajar pada siklus I dapat dilihat pada grafik berikut: 


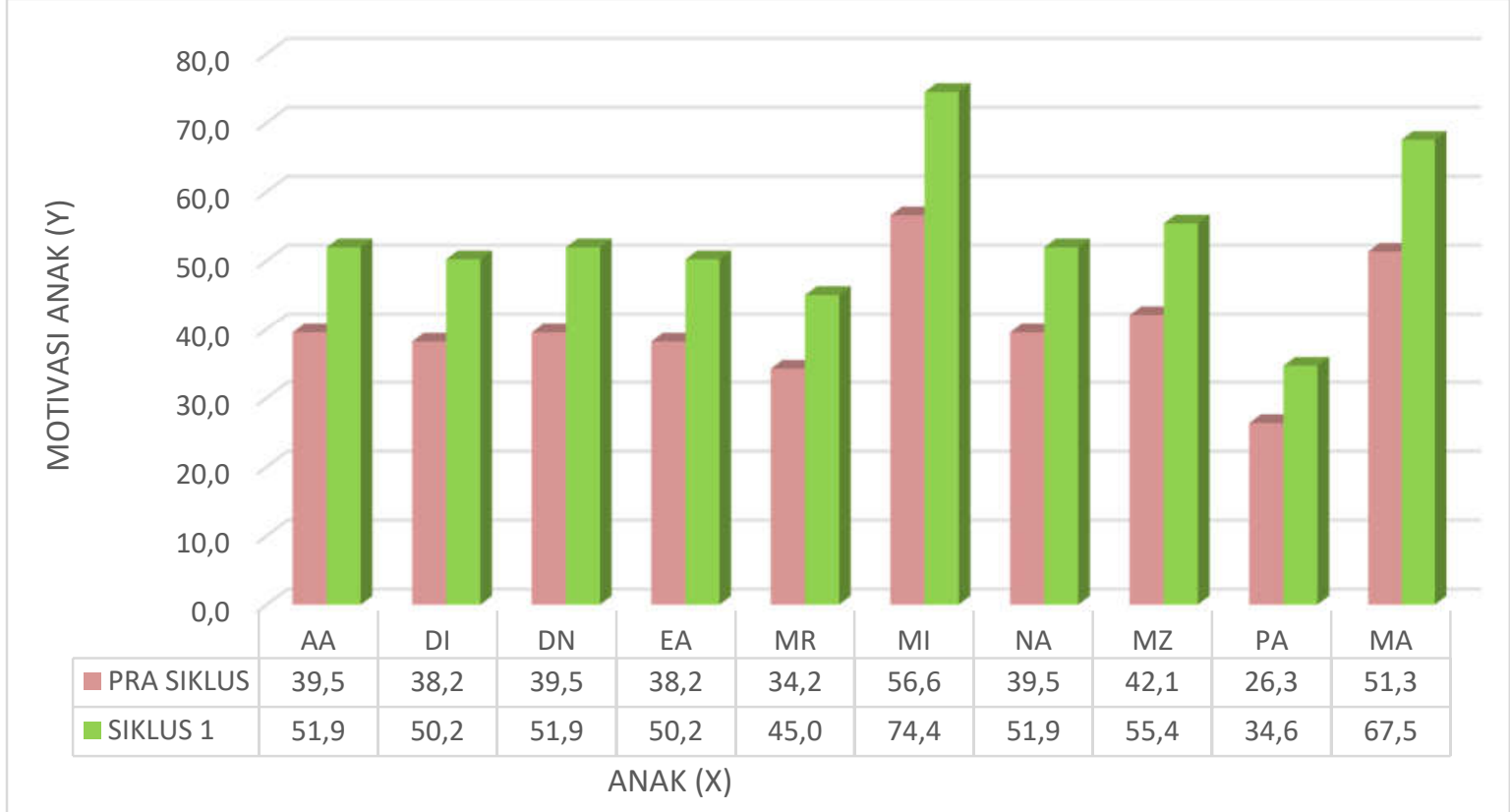

Grafik 2. Peningkatan Motivasi Belajar Anak Pra Siklus - Siklus I

Grafik dan table diatas menunjukkan hasil peningkatan rata-rata motivasi belajar anak yang diperoleh dari pra siklus ke siklus I sebesar 13,6\%. Rata-rata tersebut adalah pencapaian skor untuk motivasi belajar dari pertemuan satu hingga delapan. Anak-anak yang mendapat skor diatas rata-rata pada siklus I mengalami peningkatan adalah MI 74,4\%, MA 67,5\%, MZ $55,4 \%$. Sedangkan anak-anak yang pada pra siklus memiliki skor dibawah rata-rat mengalami peningkatan sebagai berikut: AA 51,9\%, DN 51,9\%, NA 51,9\%, DI 50,2\%, EA 50,2\%, MR $45,0 \%$, PA $34,6 \%$, pada siklus I ini anak yang mengalami peningkatan skor paling tinggi dari pra siklus yaitu MI, sedangkan untuk rata-rata persentase skornya mencapai $34,6 \%$, nilai presentase tersebut menunjukkan siswa belum mencapai standar keberhasilan tindakan yang diharapkan, sehingga harus dilakukan tindakan pada siklus II

\section{Siklus II}

Data yang diperoleh pada siklus I, belum memperlihatkan hasil peningkatan yang diharapkan, oleh sebab itu guru membuat perencanaan untuk memperbaiki kenaikan persentase pada siklus II. Hasil refleksi pada siklus I menunjukkan bahwa anak-anak sudah mengalami peningkatan yang maksimal pada setiap aspeknya, tetapi persentase keberhasilan anak pada siklus I belum mencapai $70 \%$ sesuai yang disepakati oleh guru dan peneliti. Sehingga Tindakan dilanjutkan ke siklus II untuk mendapatkan hasil yang signifikan. Pada siklus II peneliti dan guru melakukan beberapa persiapan untuk pelaksanaan tindakan , seperti: a) Menyiapkan RPPH Tema Tanah Airku sub tema Pakaian Adat, b) membuat video 
Rika Gustiani dkk (Penggunaan Vidio Pembelajaran Dalam Meningkatkan Motivasi Belajar)

pembelajaran, c) menyediakan format penilaian untuk motivasi, d) menyiapkan lembar catatan refleksi.

Siklus II dilaksanakan 8 kali, Refleksi pada setiap pertemuannya. Kegiatan yang diberikan kepada anak diantaranya: 1. Mewarnai pakaian adat Sumetera Selatan, 2. Menebalkan huruf pakaian adat, 3. Menghubungkan pakaian adat dengan rumah adat, 4. Menghitung jumlah makanan sesuai gambar, 5. Menyanyikan lagu daerah masing-masing, 6 . Hafalan Surat Al-Asr, 7. Melompat Zigzag dengan rintangan, 8. Berjalan tegap seperti bapak Polisi. Pada siklus ini, melakukan perbaikan pada tindakan yang dilakukan untuk meningkatkan motivasi anak yaitu dengan menbuat video yang lebih berkualitas baik dari segi isi materi, cahaya lampu, iringan suara music dan juga disertai dengan tampilan gambar atau tulisan yang membuat anak tidak cepat bosan untuk mengulang-ulang video pembelajaran.

Hasil Tindakan siklus II menunjukkan kenaikan skor motivasi anak di KB Baitul Falihin terlihat pada visualisasi berikut :

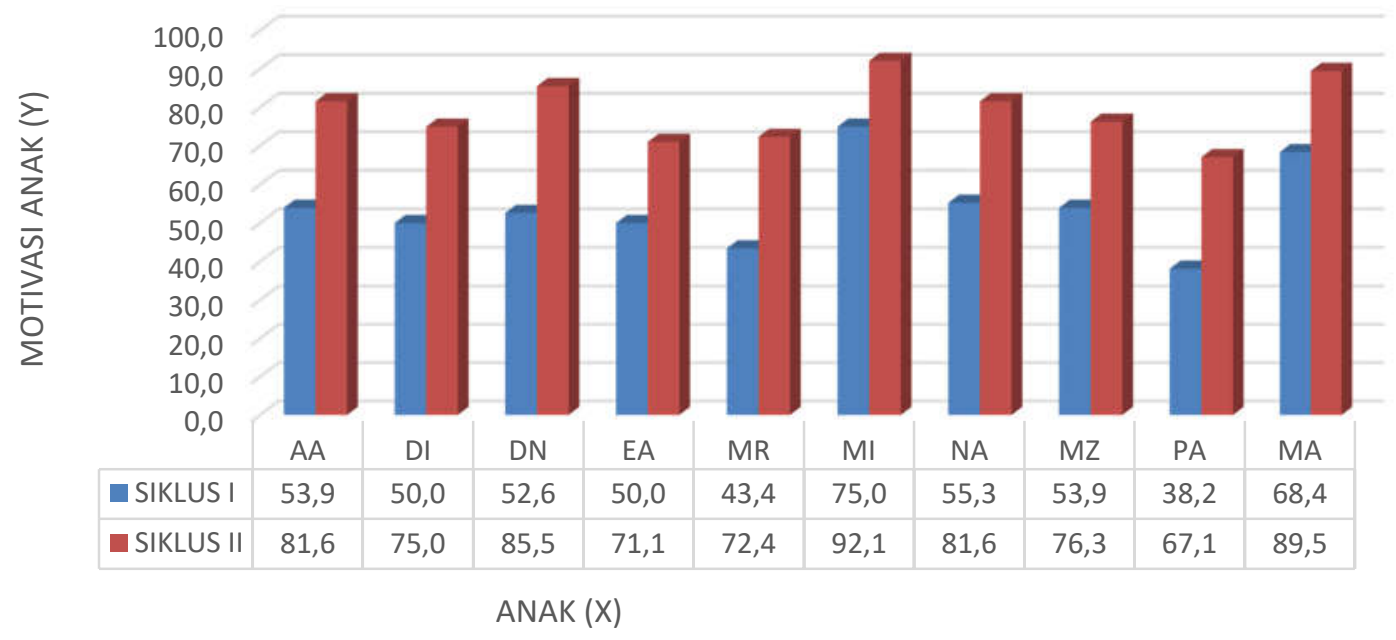

Grafik 3. Peningkatan Motivasi Belajar Anak Siklus I, ke Siklus II

Hasil Tindakan siklus II pada grafik diatas menunjukkan bahwa rata-rata motivasi belajar anak meningkat sesuai harapan dan telah mencapai standar keberhasilan. Rata -rata pencapaian motivasi belajar anak pada siklus II sebesar 79,2\%. Terdapat 5 anak yang mencapai skor diatas rata-rata kelas yaitu: MI 92,1\%, MA 89,5\%, DN 85,5\%, AA 81,6\%, NA $81,6 \%$. Rata -rata persentase kenaikan di siklus II pada setiap anak adalah $25,1 \%$. Jika ditinjau dari indikator motivasi belajar anak, maka kriterianya adalah "berkembang sesuai harapan ". Oleh karena pada siklus ini, anak-anak sudah menunjukkan hasil yang optimal dan sudah sesuai dengan apa yang diharapkan maka disepakati untuk berhenti pada siklus II.

160 AL HIKMAH: INDONESIAN JOURNAL OF EARLY CHILDHOOD ISLAMIC EDUCATION VOL.5 No.2 Tahun 2021 
Rika Gustiani dkk (Penggunaan Vidio Pembelajaran Dalam Meningkatkan Motivasi Belajar)

Hasil rata-rata peningkatan motivasi belajar dari pra siklus, siklus I dan siklus II dapat dilihat pada table dan grafik berikut ini:

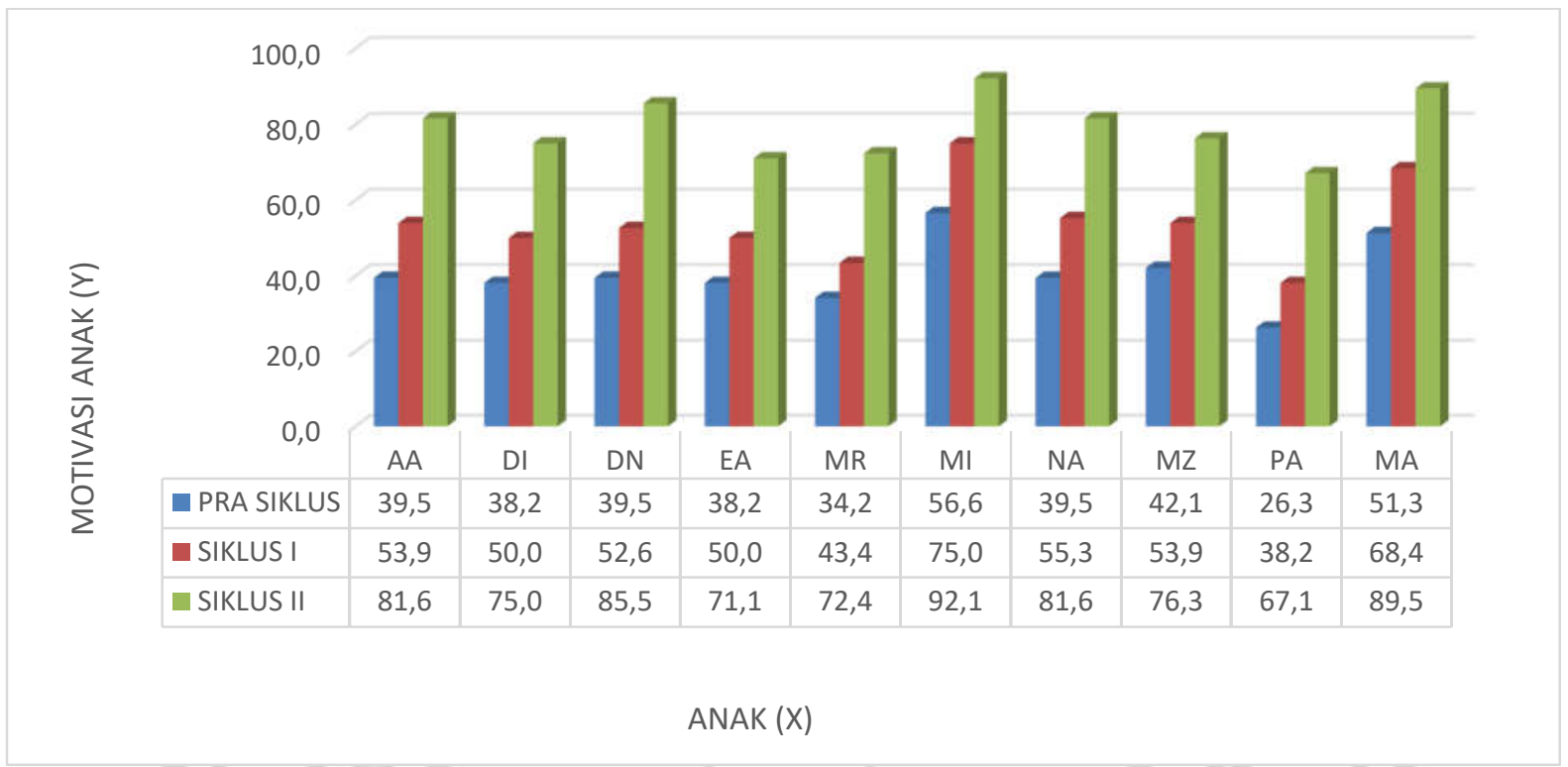

Grafik 4. Peningkatan Motivasi Belajar Anak Pra siklus, Siklus I, \& Siklus II

Grafik dan table 4 diatas menunjukkan bahwa peningkatan motivasi belajar anak usia 5-6 tahun KB Baitul Falihin dari pra siklus sampai dengan siklus yaitu 13,6\% dengan jumlah rata-rata kelas $30,8 \%$ pada pra siklus dan $54,1 \%$ pada siklus I. Setelah dilaksanakan Tindakan pada siklus II, presentase rata-rata skor motivasi belajar anak meningkat hingga 79,2\%, peningkatan dari pra siklus sampai pada siklus II sebesar 38,7\%. Hasil Tindakan siklus II menunjukkan secara keseluruhan siswa telah mencapai standar keberhasilan Tindakan 70\%.

Presentase hasil yang telah dipaparkan, menunjukkan bahwa pelaksanaan kegiatan pada siklus II menunjukkan peningkatan motivasi belajar dengan menggunakan media video pembelajaran. Perbaikan yang dilakukan pada siklus II dan refleksi pada siklus I menunjukkan pengaruh yang signifikan. Terlihat perbedaan pada siklus I Ketika anak disajikan dengan video yang natural tanpa efek atau tanpa editan dengan video yang diberi efek cahaya, suara, tulisan. Pada siklus II anak terlihat lebih bersemangat dalam mengikuti pembelajaran dirumah.

\section{Pembahasan}

Penelitian dilaksanakan untuk meningkatkan motivasi belajar anak selama pembelajaran daring dengan menggunakan media video pembelajaran yang dibuat guru. Penelitian ini dilakukan di kelompok usia 5-6 tahun di KB Baitul Falihin Karawang, dengan tahap Pra Siklus, Siklus I dan siklus II. Sebelum peneliti melaksanakan Siklus I, peneliti melakukan penelitian yang bertujuan mencari dan mengumpulkan data awal motivasi belajar anak. Pra Siklus dilaksanakan untuk mendapatkan data awal jika pembelajaran tidak menggunakan media video 
Rika Gustiani dkk (Penggunaan Vidio Pembelajaran Dalam Meningkatkan Motivasi Belajar)

pembelajaran hanya menggunakan metode penugasan yang diberikan guru kepada orangtua/wali murid, sehingga anak tidak langsung mendapat pembelajaran dari guru tetapi melalui orangtuanya.

Metode pemberian tugas secara tidak langsung kepada anak sangat membosankan bagi anak karena anak tidak bisa bertatap muka langsung dengan guru dan tidak mendapat petunjuk langsung dari guru. Melihat hasil dari Pra siklus, peneliti menggunakan media video pembelajaran pada siklus I dan terjadi peningkatan, terlihat dari pengumpulan tugas yang diberikan melalui video pembelajaran dapat diselesaikan dengan cukup baik. Hasil dari siklus I ini sudah terjadi peningkatan walaupun belum sesuai standar yang di harapkan dan di sepakati antara peneliti dan guru. Adapun standar yang di harapkan yaitu rentang nilai 70 - 86 dengan kriteria BSH (berkembang sesuai harapan). Setelah siklus I kemudian dilakukan Refleksi. Refleksi dilakukan oleh peneliti dan guru untuk membahas kekurangan untuk diperbaiki pada siklus II.

Pada siklus II, peneliti dan guru membuat video pembelajaran yang lebih menarik lagi baik dari segi isi materi, cahaya lampu, iringan suara music dan juga disertai dengan tampilan gambar atau tulisan yang membuat anak tidak cepat bosan untuk mengulang-ulang video pembelajaran. Setelah diadakan perbaikan pada media video pada siklus II ini pencapaian motivasi belajar anak semakin meningkat, terjadi peningkatan yang baik sesuai dengan Harapan.Hasil nilai yang diperoleh adalah sebesar 79,2.

Dengan penggunaan media video pembelajaran yang dibuat guru yang dampaknya motivasi belajar anak meningkat, dan secara langsung dapat menarik minat dan perhatian anak, karena yang hadir dalam video pembelajaran itu adalah guru mereka sendiri. guru menyapa anak-anak, mengajak berdoa, bernyanyi, memberi motivasi dan memberikan penjelasan tentang tema yang akan dipelajari dengan menarik. Hal ini sejalan dengan teori Arsyad (2011:24), yang menyatakan manfaat media membuat anak tertarik dan dapat menumbuhkan motivasi belajar. Teori lainnya yang mendukung pendapat diatas menyatakan bahwa Media video pembelajaran dapat memberikan pengalaman belajar yang tidak terduga bagi anak sehingga media video dapat dimanfaatkan dalam program pembelajaran. Daryanto (2012:87)

\section{PENUTUP}

\section{Simpulan.}

Pemilihan media pembelajaran yang tepat pada saat pembelajaran daring sangat berpengaruh terhadap motivasi belajar anak.Penggunaan video pembelajaran adalah salah satu

162 AL HIKMAH: INDONESIAN JOURNAL OF EARLY CHILDHOOD ISLAMIC EDUCATION VOL.5 No.2 Tahun 2021 
Rika Gustiani dkk (Penggunaan Vidio Pembelajaran Dalam Meningkatkan Motivasi Belajar)

media yang disarankan oleh pemerintah dalam memfasilitasi pembelajaran dari rumah. Rencana pembelajaran yang memadai harus dipersiapkan dengan baik untuk memotivasi belajar anak dengan menggunakan media video pembelajaran . Mulai dari membuat rencana pembelajaran harian, membuat video yang menarik yang akan dikirimkan ke grup kelas agar anak tertarik sehingga motivasi belajarnya berkembang. Berdasarkan hasil analisis data pra penelitian didapatkan rata -rata persentase motivasi belajar anak sebesar 40,5\%. Pada siklus I, setelah dilakukan tindakan dengan menggunakan media video yang dibuat oleh guru, terjadi peningkatan motivasi belajar anak sebesar $54,1 \%$, tetapi hasil ini belum sesuai dengan target pencapaian yang disepakati yaitu $70 \%$ atau nilai perkembangan minimal 70 , sehingga tindakan dilajutkan ke siklus II. Setelah dilakukan tindakan perbaikan pada video pembelajaran, terjadi peningkatan motivasi belajar anak yang signifikan yaitu sebesar 79,2\%.

Dengan demikian berdasarkan hasil Analisis dan pengamatan siklus I dan Siklus II dapat disimpulkan bahwa penelitian tindakan kelas melalui penggunaan media video pembelajaran dapat meningkatkan motivasi belajar anak usia 5-6 tahun di KB Baitul Falihin Karawang

Saran

Dengan adanya video pembelajaran yang dibuat oleh guru, anak akan merasa seperti sedang belajar disekolah karena anak akan mendapatkan penjelasan sesuai dengan materi yang disampaikan dan dapat diulang-ulang. Oleh karena itu untuk peningkatan kompetensi, guru perlu dibekali dengan pelatihan untuk meng edit video melalui berbagai aplikasi agar video yang dibuat semakin menarik karena media video pembelajaran ini bisa digunakan untuk beberapa tahun kedepan selama bahan ajarnya sama.

\section{DAFTAR PUSTAKA}

Arikunto, S. (2009). Penelitian Tindakan Kelas. Jakarta: Bumi Aksara.

Arsyad, A. (2016). Media Pembelajaran. Jakarta: Raja Gravindo Persada.

Batubara \& Hamdan Husein. (2020). Penggunaan video Tutorial untuk mendukung Pembelajaran Daring di masa Pandemi virus Corona. Banjarmasin, Indonesia: Muallimuna Jurnal Madrasah Ibtidaiyah.

Cheppy Riyana, (2012). Pedoman Pengembangan Media Video. Jakarta: P3AI UPI

Daryanto. (2012). Media Pembelajaran. Bandung: Satu Nusa.

Daryono. (2016). Media Pembelajaran. Yogyakarta: Gaya Meida

Fadlilah dkk (2020). Strategi Menghidupkan Motivasi Belajar Anak Usia Dini Selama Pandemi COVID19 melalui Publikasi . jurnal Obsesi: jurnal Pendidikan Anak Usia Dini

163 AL HIKMAH: INDONESIAN JOURNAL OF EARLY CHILDHOOD ISLAMIC EDUCATION $\mid$ VOL.5 No.2 Tahun 2021 
Rika Gustiani dkk (Penggunaan Vidio Pembelajaran Dalam Meningkatkan Motivasi Belajar)

Hamzah,B Uno. (2014). Teori Motivasi dan Pengukurannya Analisis diBidang Pendidikan. Jakarta: Bumi Aksara.

Heidy Ayu R,Lukita Nurul H, Aisyah Agus S, Hernik F. (2020). Media Video Animasi untuk mengoptimalkan Perkembangan Kognitif Siswa RA Sunan Ampel Pasuruan. Surabaya, Indonesia:Al Hikmah :Indonesian Journal of Earli Childhood Islamic Education.

Hayati dkk. (2021). Pemanfaatan Youtube Channel Cocomelon sebagai media pengenalan kota kata Bahasa Inggris Anak Surabaya, Indonesia:Al Hikmah :Indonesian Journal of Earli Childhood Islamic Education.

Ine Nirmala \& Feronica Eka Putri. (2017). Peningkatan Kreativitas Anak Melalui Pemanfaatan Barang Bekas. Karawang, Indonesia: Jurnal Pendidikan Pascasarjana Magister PAI

Wiriatmadja. (2012). Metode Penelitian Tindakan Kelas. Bandung: Remaja Rosda Karya

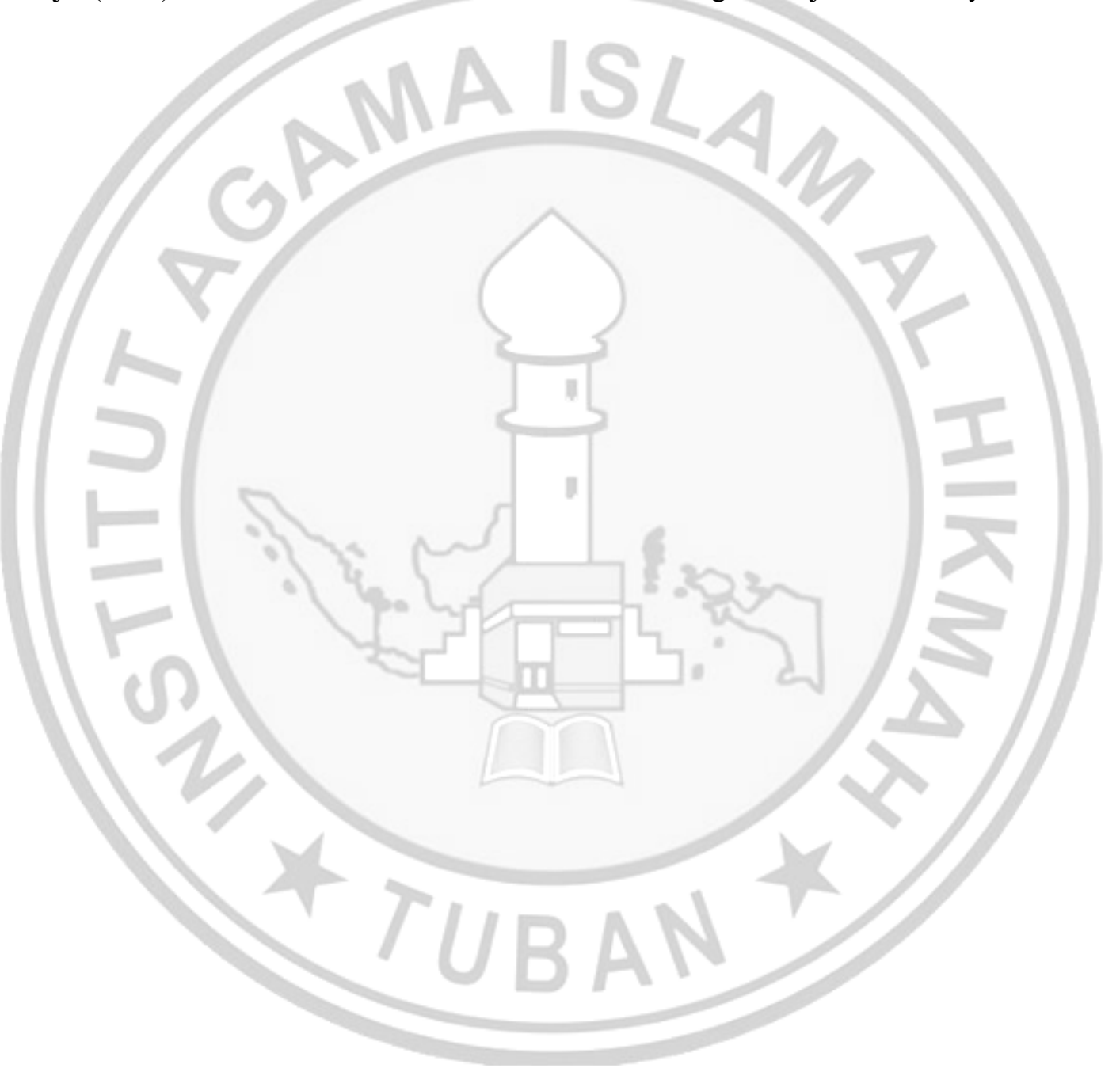

